University of Nebraska - Lincoln

DigitalCommons@University of Nebraska - Lincoln

Publications of the University of Nebraska

Public Policy Center

Public Policy Center, University of Nebraska

2019

Disrupting Narrow Conceptions of Justice: Exploring and Expanding "Bullying" and "Upstanding" in a University Honors Course

\author{
Jennifer Farley \\ University of Nebraska-Lincoln, jfarley3@unl.edu \\ Jennifer Gallagher \\ East Carolina University, gallagherj17@ecu.edu \\ Katherine Richardson Bruna \\ lowa State University, krbruna@iastate.edu
}

Follow this and additional works at: https://digitalcommons.unl.edu/publicpolicypublications

Part of the Other Public Affairs, Public Policy and Public Administration Commons, Other Social and Behavioral Sciences Commons, Public Affairs Commons, Public Policy Commons, and the Social Policy Commons

Farley, Jennifer; Gallagher, Jennifer; and Bruna, Katherine Richardson, "Disrupting Narrow Conceptions of Justice: Exploring and Expanding "Bullying" and "Upstanding" in a University Honors Course" (2019). Publications of the University of Nebraska Public Policy Center. 197.

https://digitalcommons.unl.edu/publicpolicypublications/197

This Article is brought to you for free and open access by the Public Policy Center, University of Nebraska at DigitalCommons@University of Nebraska - Lincoln. It has been accepted for inclusion in Publications of the University of Nebraska Public Policy Center by an authorized administrator of DigitalCommons@University of Nebraska - Lincoln. 

1746197919853808

Copyright @ 2019 Jennifer Farley, Jennifer Gallagher, and Katherine Richardson Bruna. Published by SAGE. Used by permission.

Published online June 27, 2019.

\title{
Disrupting Narrow Conceptions of Justice: Exploring and Expanding "Bullying" and "Upstanding" in a University Honors Course
}

\author{
Jennifer Farley, ${ }^{1}$ Jennifer Gallagher, ${ }^{2}$ and Katherine Richardson Bruna ${ }^{3}$
}

1. University of Nebraska-Lincoln, Lincoln, Nebraska, USA

2. East Carolina University, Greenville, North Carolina, USA

3. Iowa State University, Ames, Iowa, USA

Corresponding author - Jennifer Farley, University of Nebraska-Lincoln, 212 Barkley Memorial Center, Lincoln, NE 68503, USA, email jarley3@unl.edu

\begin{abstract}
The term "upstanding" encompasses actions and behaviors grounded in one's defense of their own beliefs and others. While such broad application of the term has merit, from a critical education perspective it lacks direction. To efficaciously address injustice, upstanding action must go beyond one's beliefs. A directional application of upstanding behavior, or the notion of "upstanding for justice," frames upstanding as action to address chronic social victimization via systems of oppression. In this article, we describe the development of a new heuristic to support students' understanding of upstanding and detail the university honors course in which we used the heuristic to explore the phenomena of "bullying" and historical injustice to expand ideas of "upstanding." Results indicate that students in the course broadened their conceptions of justice, and the use of historical cases aided in their understanding of the interplay between individual agency and social structure in social justice efforts.
\end{abstract}

Keywords: bullying, bystander, civics education, social justice, upstanding

Programmatic and pedagogical responses to school bullying and civic education are constrained by conceptual limitations. The first limitation involves a situational, not systemic, 
understanding of the causes of bullying behavior. In school bullying, for example, individuals who intervene on behalf of a person targeted by bullying behavior are known as upstanders (Upstander, n.d.), but the conceptual understanding of upstanders and their actions rarely addresses that bullying behavior is often a manifestation of larger societal injustices. The most obvious example of this is identity-based bullying (Chatters and Zalaquett, 2018; Swearer and Hymel, 2015) which targets, for instance, sexual orientation, reflective of heteronormative hierarchies, and discrimination. Discussions about school bullying which targets real or perceived sexual orientation will call for "upstanding," but they stop short of interrogating the discrimination that exists in the school and community environment that breeds the bullying behavior to begin with. The second limitation, on the other hand, involves a focus on the systemic framework of civic education without attention to situational manifestations requiring individual action and what the nature of such action could be. While civic education is often taught through social justice-oriented definitions (Westheimer, 2015; Westheimer and Kahne, 2004), it rarely makes the long journey from the collective combatting of a societal injustice such as racism, to individual interpersonal actions, such as upstanding in an incident of racialized bullying. We believe that an intersection of these fields, school bullying, and social justice-oriented civic education can address these limitations and provide powerful understandings for helping individuals see themselves not just as upstanders in bullying but upstanders toward justice.

As critical education scholars, we are united in our efforts to better understand how to prepare undergraduate students to be agents of change in an unjust world. From the stances of our particular subfields - school climate, social studies education, and multicultural education - we have found the notions of upstanding and bystanding to have particular utility in helping young adults conceptualize themselves and their actions within a broader behavioral and ethical landscape, and in this way advance their development along a continuum of sociocultural consciousness (Villegas and Lucas, 2002). Through our collective experience in undergraduate education, we identified the need for a model that would connect small, individual acts of upstanding in the face of bullying to civic education for social justice. We are connected in this interest because of our involvement with a Facing History and Ourselves (FHAO) teacher education initiative. FHAO is a long-standing international education and professional development organization dedicated to providing teachers with content resources and pedagogical strategies to have classroom dialogue about difficult social topics (www.facinghistory.org). One of our early experiences with FHAO, introduced us to the Pyramid of Hate created by the Anti-Defamation League (2018), which illustrates the relationship between individual and collective behaviors which expand from biased attitudes (e.g., microaggressions, stereotyping) to discrimination (e.g. economic, political, educational) to genocide (Anti-Defamation League, 2018). As educators, we found the Pyramid of Hate to be a valuable visual representation of the connections we helped our students make between actions within schools, such as school bullying, to larger issues of social injustice. This caused us to wonder whether a similar visual would be useful in helping students understand what it means to be an ally. If the Pyramid of Hate can effectively illustrate how individual hateful acts lead to the ultimate injustice of genocide, can we flip the heuristic? Conversely, can we illustrate for our students how 
individual ally behaviors can lead to social change and justice? Would this help them see themselves as "upstanders towards justice"?

In this article, we describe how some foundational tenets, practices, and resources within our fields, such as bystander intervention theory, historical thinking, political philosophy, and sociocultural learning theory, helped us to design a new heuristic that would facilitate students' deeper understandings about the interplay between individual agency and social structure in social justice efforts. We detail the university honors course in which we used the heuristic and an associated curriculum to explore the phenomena of "bullying," expand the goal of "upstanding," and broaden conceptions of justice among undergraduate students at a primarily white institution. We document the research process to identify the impact of the course on students' conceptions of "upstanding toward justice." And, we discuss how the curricular use of historical cases highlight the situated nature of behavior as construed through context and identity, supporting students to identify multiple ways that an individual action, such as bullying, connects to societal oppression, and can be responded to with a plethora of actions considered "upstanding for justice." We begin, in the literature review that follows, by laying a foundational understanding of upstanding, bystanding, and bystander intervention, and justice.

\section{Literature review}

\section{Understanding upstanding}

In 2016, the Oxford dictionary adopted the following definition of an upstander: a "person who speaks or acts in support of an individual or cause, particularly someone who intervenes on behalf of a person being attacked or bullied" (Upstander, n.d.; Zimmer, 2016). While the term bystander has been traditionally used to describe individuals who may witness bullying or emergency situations, upstanders differ from bystanders in terms of the speech or action they take in response to a witnessed event. More precisely, upstanders are bystanders taking action to intervene. The study of bystander intervention answered the call for broader research of societal norms following the 1964 murder of Kitty Genovese, during which as many as 38 bystanders witnessed the event and failed to respond (Latane and Darley, 1970). This event prompted Latane and Darley (1970) to investigate bystander intervention and produce groundbreaking studies of the "bystander effect" building the foundation for how we conceptualize upstanding in this article.

\section{Bystanders and bystander intervention}

To understand the nature of human response in emergency and criminal situations, scholars sought to isolate features of behavior culminating in action on behalf of someone being victimized and then use these for pedagogical purposes. Latane and Darley's (1970) Bystander Intervention Framework identifies a "series of decisions" which lead a bystander to take action (p. 31). This decision-making process includes five stages: (1) notice the event, (2) interpret the event as an emergency, (3) determine it is their responsibility to act, (4) determine how to help, and (5) implement action (Latane and Darley, 1970: 31-32).

Bystanders may choose to act for a number of reasons including a sense of moral obligation, altruism, low personal cost, likely positive outcome, and social norms which promote 
helping (Banyard et al., 2004; Baston, 1995; Chabot et al., 2009; Garcia et al., 2009; Olweus et al., 2007; Time et al., 2010). However, bystanders don't always take action. The bystander may not recognize the event as an emergency, know how to respond, or may fear becoming a victim (Chabot et al., 2009; McIntyre, 1994; Shibata et al., 2008; Time et al., 2010; Wenik, 1985). The presence of other bystanders also influences action. Table 1 details the negative effects that other bystanders may have on an individual's action.

\begin{tabular}{|c|c|c|}
\hline Bystander effect & Definition & Source \\
\hline Evaluation apprehension & $\begin{array}{l}\text { Fear that others present may evaluate the } \\
\text { bystander's actions in a negative way }\end{array}$ & Fischer et al., 2006: 267 \\
\hline Audience inhibition & $\begin{array}{l}\text { Desire "to engage in helping behavior" but } \\
\text { feel "restrained from doing so because of the } \\
\text { presence of others who are not helping" }\end{array}$ & van den Bos et al., 2009: 873 \\
\hline Pluralistic ignorance & $\begin{array}{l}\text { Bystander second-guesses their perception of } \\
\text { an emergency because they believe others do } \\
\text { not identify the events in the same way }\end{array}$ & Prentice and Miller, 1996 \\
\hline Diffusion of responsibility & $\begin{array}{l}\text { Feeling of shared responsibility to act with } \\
\text { other bystanders, rather than alone }\end{array}$ & Schwartz and Gottlieb, 1980 \\
\hline
\end{tabular}

Applications of upstanding

While the term "upstander" was only recently added to the dictionary, the first use of the word was credited to U.S. Ambassador to the United Nations Samantha Power, who in 2002 differentiated "standing up" and "standing by" (Zimmer, 2016). However, since 2002 researchers, advocacy groups, and classroom curricula apply the term "upstanding" to a diverse set of behaviors and context. The bullying prevention literature narrowly defines upstanding behavior as action which "defends" the target and may involve confronting the student perpetrating bullying behavior (Olweus, 2003; Salmivalli, 2014; Salmivalli et al., 1996; Sutton and Smith, 1999) and Latane and Darley's bystander intervention framework has been applied to explore teacher and student behaviors (Farley, 2018; Pozzoli and Gini, 2013). Advocacy groups (e.g., The Bully Project, NoBullying.com, Be the Change NZ) more broadly define upstanding behavior. For example, the Bully Project defines an upstander as "someone who recognizes when something is wrong and acts to make it right... In many ways, this is another word for being socially responsible" (You're An Upstander, n.d.). Furthermore, curricular resources, such as FHAO, define upstanders as individuals who "stand up for what they believe in" which results in a "more peaceful and just world" (Who Is an Upstander, n.d.). Such broad definition and unspecific application of the term "upstander" outside of research could be problematic to the promotion of social justice (despite the obvious application toward social justice in these organizations' resources). Definitions which encourage upstanding for beliefs and against something "wrong" may be applied to a number of unjust beliefs (e.g., white supremacy, patriarchy, homophobia) and rights deemed "wrong" by those beliefs (e.g., interracial marriage, equal pay, adoptive rights for same sex couples).

From a critical education perspective, the broad use of the term upstander has merit yet currently lacks direction. For example, in the current framing of upstanding, individuals 
may upstand in incidents unrelated to social justice such as going out of their way to help someone who has dropped their books in a busy hallway. Or, within the current framing, it might be considered upstanding to vocally support causes antithetical to social justice, for example, one might upstand for exclusionary school policies. However, to efficaciously address injustice, upstanding action must go beyond one's beliefs about situations and be aligned with social justice. A directional application of upstanding behavior, or the notion of "upstanding for justice," will support students to frame upstanding as action to address chronic social victimization via systems of oppression, and in this way think about how their daily actions reproduce or resist power dynamics.

\section{Understanding justice}

Upstanding is directional in nature; it implies that someone is taking action "standing" for someone or something in service of an upright ideal associated with justice. But despite the ubiquitous use of the term "justice," from a theoretical standpoint its meaning is quite contested. Theories of justice span a wide political and philosophical landscape. These include theories that evaluate justice by: the liberties of the individual (e.g., Nozick), the goodness of the community (e.g., Sandal), the cultivation of individual capabilities that the community supports (e.g., Sen and Nussbaum), or the absence of unjust oppression (e.g., Young).

Much education scholarship attempting to define social justice-oriented citizenship uses the framework of Westheimer and Kahne (2004) (Westheimer, 2015). These authors define a social justice-oriented citizen as one who (a) "Critically assesses social, political, and economic structures to see beyond surface causes," (b) "Seeks out and addresses areas of injustice," and (c) "Knows about social movements and how to effect systemic change" (Westheimer and Kahne, 2004: 240). However, this framework lacks any operational constructs for defining what social justice actually means.

To address these limitations, we developed the Upstanding for Justice Heuristic (UJH) (Fig. 1). According to Narismulu (2013), the word heuristic "refers to the experience-based techniques that help in learning, discovery and problem solving," (p. 790). In our own work with undergraduates, we came to feel the need for a tool that would help them learn to historicize, consider context, discover broader factors which influence upstanding, and problem-solve in ways oriented to justice. In the way that the UJH organizes action and accounts for context, we propose it as a constructive alternative to the Pyramid of Hate (Anti-Defamation League, 2018). In the way that upstanding behavior and democratic resistance have been explored with students using the Anti-Defamation League's (2018) Pyramid of Hate and historical cases of injustice (Welsh, 2014), we sought to use a similar approach with our UJH. We aimed to be forthright with students that our particular heuristic used a theory of justice framed through the work of political philosopher Nancy Fraser (Dahl et al., 2004). However, at the end of the course, we created a project in which the students would need to create their own heuristic framed by a vision of justice they wanted to upstand toward. 


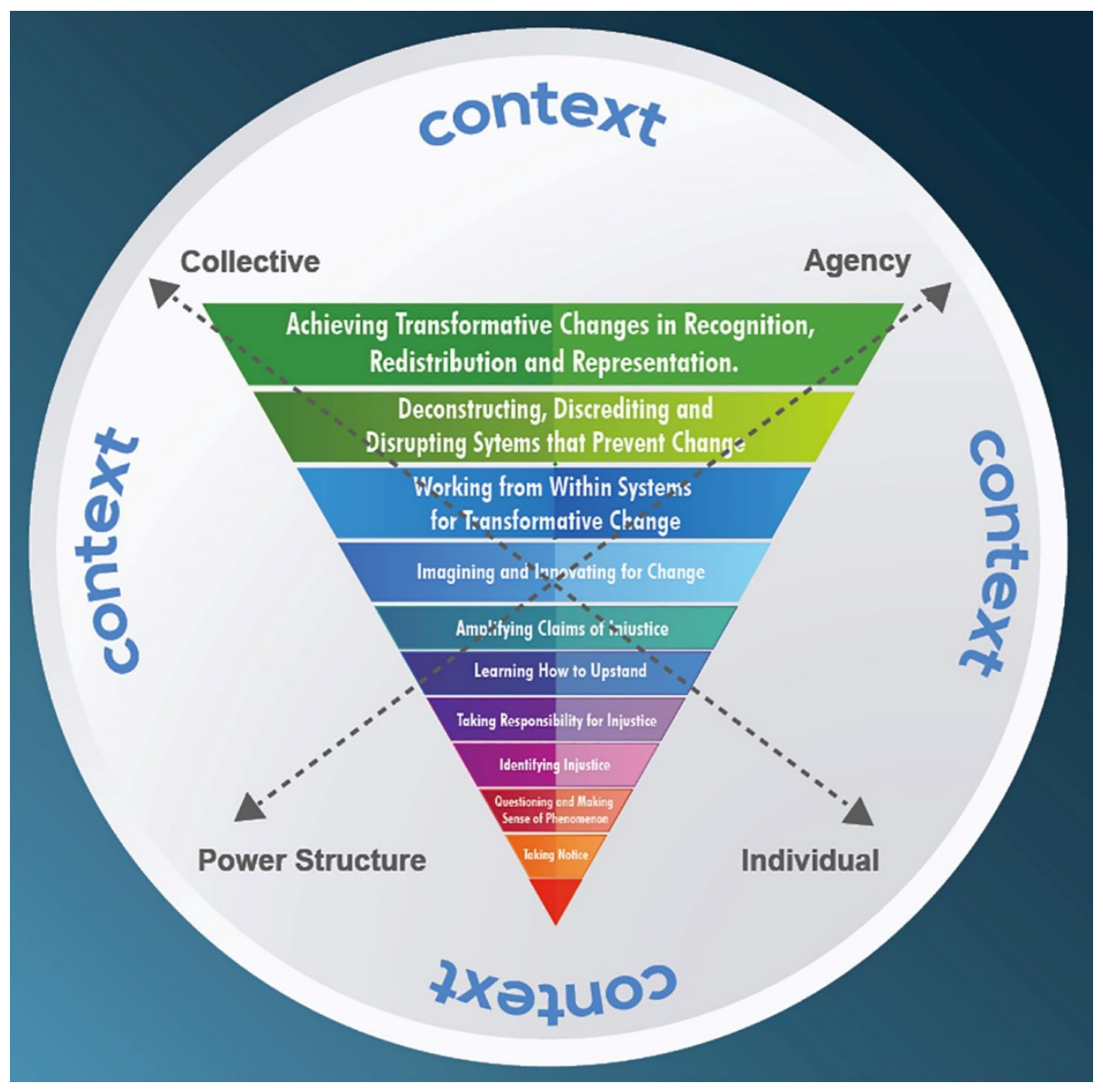

Figure 1. The Upstanding for Justice Heuristic

We piloted the UJH in a course, "Upstanders for Justice," that we ran through our university's Honors College. As the central analytic device in the course, the heuristic served as a tool for students to critically analyze historical cases, explain their constituent components, and organize justice-oriented action in an effort to solve a problem. The work required students to consider the broader context in which both individual and collective upstanding can and will take place, and in this way advances the need in civic education for "more effective principles and practices, as well as the capacity to address systemic challenges" (Narismulu, 2013: 788).

Next, we describe our approach to studying the "case" of our implementation of the UJH. We explain the general pedagogical philosophy surrounding its use, the course context, and students as well as the curricular and instructional approach. We then detail the data collected, outline and interpret themes, and conclude by identifying key implications for its continued use. 


\section{Methodology}

To understand the potential of the UJH heuristic and our "upstanding for justice" curriculum, we developed two research questions to explore our students' meaning-making throughout the University Honors course (a) What are conceptions of justice and upstanding held by students prior to and after the course intervention? (b) What role does course curriculum and pedagogy (historical inquiry thinking, use of heuristics, readings in political philosophy) play in deepening students' conceptions of justice and upstanding?

An upstanders' community of practice: a situated perspective

Our research assumes a situated perspective on teaching and learning in which all learning is viewed as practices situated in particular contexts and communities (Engestrom, 2000; Lave and Wenger, 1991; Vygotsky, 1980). A situated learning perspective requires a deep engagement with the sociopolitical identities of participants, their intersectional social identities, their histories, and their engagements in multiple discourse communities. Situated learning theory is important in this work because it attempts to understand students' views of their own understanding and agency toward justice while those views are changing as they move from the periphery toward the center of an upstander community of practice. Integral to situated learning is the idea of apprenticeship in which a more expert member serves to socialize the more novice member into the practices definitional to the community. As instructors of the course, Farley and Gallagher acted as more expert members to apprentice students by facilitating their discussions and thinking about upstanding. The nature of their interactions in modeling interrogation of justice theories, historical thinking, and historical narration served to shape the situated context of civic learning for civic development and engagement in the Upstanding for Justice course.

We present our research in the form of a case. Case study design binds the research problem to a particular system in a context (Merriam, 1998). Case studies seek "meaning and understanding" through close examination of a "specific, complex, functioning, thing" (Stake, 1995: 2) which results in a richly descriptive product that is helpful in understanding a larger phenomenon (Merriam, 2002: 179; Rossman and Rallis, 2012). According to Merriam (1998), case study is "an especially good design for practical problems" (p. 11). Our case explores the impact of course curriculum as well as the example and development of Upstanding for Justice heuristics on the challenges associated with supporting students' civic identity development and upstanding behavior related to social justice.

\section{Community context}

Our examination of this problem is bound to our site of implementation-a 2-credit honors seminar offered at a university located in the Midwest over eight weeks. The course met for a 50-minute period twice a week. The situation of this course on a college campus is unique given that research, advocacy, and curricular resources specific to upstanding are typically focused on K-12 environments. However, part of the history of institutions of higher education in the United States is their charge to advance morality through a civicscentered curriculum (Yanikoski, 2004). Today, civic development is typically supported by curricular and co-curricular opportunities for community service or service learning. 
However, gaps exist in the literature regarding exactly how civic engagement opportunities in higher education affect civic and democratic learning and development (Carnegie Foundation for the Advancement of Teaching, 2006, as cited in Biddex, 2014). Critical educational scholars express concern that service learning opportunities may viewed by students as simply "volunteering" rather than addressing social or political problems (Biddex, 2014; Finley, 2011; Lopez et al., 2006), creating meaningful change, or enhancing democratic participation (Biddex, 2014; Bryant et al., 2011; Butin, 2012). In this way, current opportunities fail to achieve civic action, which requires directly "teaching students the value of collaborative and direct action" (Biddex, 2014; The National Task Force, 2012). This course, however, was designed to utilize curriculum and pedagogies related to upstanding behavior; resources which interrogate the idea of collective action and behaviors which support it. While college campuses may not be a typical context for research, advocacy, and curricular resources which highlight upstanding, the curriculum and pedagogical practices specific to upstanding may support higher education goals around civic development and action. Furthermore, research literature tells us that although a small percentage of college students major in philosophy coursework (National Center for Education Statistics (NCES), 2014), where they might engage in the contested ideas of justice, college remains an important space where educational interventions can have important influences on individuals social and political identity (Beaumont et al., 2006). Given this, it is important to recognize that the students and facilitators of the course are already members of a broader university. While opportunities may not exist elsewhere for course participants to study philosophy or engage with contested ideas of justice, college campus membership may prime students to interrogate their personal beliefs related to their social and political identity, wrestle with concepts of justice, and seek opportunities to take action.

\section{Community members}

The course included 11 undergraduate honors students and two facilitators. Participants were enrolled in majors across the university and were diverse in how they self-identified throughout the course including identification as "multicultural," "Queer-Latina," "Man," "Male," and "Female." The instructors both self-identified as a white, straight, cisgender women. Our intent was to understand the situated and complex learning phenomena produced by the enactment of our curriculum to contribute in a practical way to civic education for social justice.

\section{Upstanding for justice curriculum and pedagogy}

The honors seminar was an ideal setting to explore "upstanding for justice," as the purpose of the seminar was to dialogue within the intersection of a number of different fields and ideas relevant to our examination of justice theories and behaviors. The goal of the course was for students to contemplate their own identities as upstanders for justice. This was achieved through course readings, which included political philosophy, bystander intervention and historical cases, use of historical inquiry thinking, utilization of our "upstanding for justice" heuristic (see Fig. 1) to make sense of upstanding behavior, self-reflection, and class discussion. During the course, course readings of upstanding literature and political philosophy (e.g., Nozick, Nussbaum, Sandel, and Young) first supported students' 
constructions of justice, and then students were asked to attempt to conceptualize a personal theory of justice.

\section{Historical inquiry thinking}

The course utilized historical inquiry tools, such as primary sources and historical thinking analysis questions, to allow students to analyze historical texts and artifacts while also supporting their ability to identify upstanding behavior and contemplate effects of the sociocultural context. Historical thinking, previously conceptualized as historical narration, "is a system of mental operations defining the field of historical consciousness" (Rüsen, 1987). Historical narration can make the present time understandable and the future time anticipated, in this way making the past relevant to continuing temporal social change. Studies in secondary schooling contexts indicate that studying historical agency encourages students to think about their own agency (den Heyer, 2003). Recently, more specific historical inquiry practices have emerged from expert/novice research that include analyzing historical sources for attribution, perspective, and reliability (VanSledright, 2004) as well as situating sources in context (Wineburg et al., 2012). Within the course, students analyzed primary sources from the U.S. Civil Rights Movement (which we defined as the struggle for a broad range of human rights extending from 1492 to today) with the heuristic to identify upstanding behavior within the historical case. Use of historical inquiry thinking supported students to unpack complexities of the social world that cut across historical time periods or issues of justice and draw parallels with contemporary issues of justice and desired upstanding behavior. Ultimately, we hoped that use of historical inquiry thinking with the historical cases and heuristic would support students to grasp more profoundly how structural constraints and individual agency intersect in a meso space providing opportunity for upstanding action and justice envisioning.

\section{Data collection}

We collected all data with course assignments submitted through the university's Blackboard system, including weekly "entry tickets" and journal entries. Next, we coded all course assignments with Dedoose, a software that supports coding in qualitative research. This included applying single root codes to students' writing as well as double or triple axial coding (Bohm, 2004) when there was data to support interconnectedness between the root codes. After initial coding, we exported excerpts (by code) to Excel for a second round of coding, through which subthemes emerged from the data. Finally, we developed a code book to keep track of these emerging themes and our related insights throughout this process. The findings that follow represent the most salient themes that emerged from the data.

\section{Findings}

\section{Complicating justice and upstanding: insights about civic learning and development}

While analyzing findings for our research questions-(a) What are conceptions of justice and upstanding held by university honors students' prior to and after the course intervention, and (b) What is the role of course curriculum and pedagogy (historical inquiry 
thinking, use of heuristics, readings in political philosophy) in deepening students' conceptions of justice and upstanding - three subthemes emerged. These themes helped us understand how the course complicated students' conceptions of justice: their definitions of justice and upstanding were broadened, their notions of upstanding moved from singular and contextual to diverse and justice-oriented, and their new conceptions of upstanding were grounded in identity and context.

\section{Broadening definitions of justice}

For the most part, students came to the course with narrow conceptions of justice. Many of them focused on law, the dynamic of crime and punishment, and a few brought the notion of equality. A course practice that complicated their vision of justice was exposure to theoretical ideas about justice from contemporary political philosophers. A journal entry from Student 9 after the first week of class speaks to this effect:

Something that has really stuck with me so far this week is the concept of justice. I, and probably many others, have typically, if not always, considered it with punishment in mind. Previously I never really thought for more than a fleeting moment that justice could also be applied to someone who may have been a victim of a situation rather than a perpetrator. I like that justice can refer to bringing something good to a victim (separate from punishment of a perpetrator, as I view that as unpleasant but necessary), such as money and supplies after someone's house had burned down or transportation after their car was stolen. It brings the concept into a whole new perspective, as I see it.

In another case, exposure to political philosophy seemed to "flip" a student's thinking about the direction of justice. Student 4 wrote:

While everyone supports justice, not everyone can agree on what justice means. This is at the core of why it is hard to determine a vision of justice for society. Young's 5 Faces of Oppression lays out the idea that "structural oppression" can exist in five different "faces," or forms as I have come to understand it. By defining these obstacles to justice, Young has flipped the way I think about justice. Originally, I thought about justice as the actions that are taken to counter what is morally wrong. Since action is the end of any movement for change, my old train view would see justice as actions taken in the past to make society just. While this allowed me to appreciate the work of civil rights leaders, suffragettes, abolitionists and others, this idea does lend itself to thinking about what injustices should be removed next. I was looking backwards because I did not see myself or those around me as being treated unjustly. Now, I see justice as the absence of oppression, which is a definition that serves as a call to eliminate oppression wherever it exists. 
In one student's meaning-making, the political philosophy readings and ensuing discussion broadened his idea of justice by "scaling up" how he thought about justice or injustice. Student 9 wrote:

Young's five faces of oppression didn't change my general idea or opinion of justice, but it opened my eyes to how unlimited justice (or injustice) can be. I typically think of more simply explained social situations, such as marriage rights for homosexuals. I hadn't considered oppression on a greater scale, with the exception of major events such as slavery or women's suffrage. Marginalization, among other forms of oppression that Young presented, was something I was aware of subconsciously but never truly considered or gave acknowledgement to, and I'm glad that I can now recognize these faces of oppression in daily life.

Overall, expansion of the students' understanding and vision of justice was paramount to their understanding of upstanding. In utilizing the heuristic (Fig. 1), "justice" is situated at the top and is the ideal to be worked toward, or that which students are upstanding for. However, as notions of justice are expanded, so are the actions and behaviors, or upstanding (both individual and collective) which that seeks to achieve justice.

\section{Expanding toward diverse, justice-oriented ideas of upstanding}

Expansion toward more justice-oriented ways of thinking about upstanding accompanied a broadening understanding of justice. For example, in a Week 1 reflection, after a session focused on bystander theory, a student used the following example to describe factors of upstanding behavior:

In the Kitty Genovese stabbing, the number of people that witnessed the event may have influenced the bystanders' decisions not to respond to the situation under the assumption that someone else would intervene. This last effect is something that I have personally witnessed in my life. For example, when a student fell off of his bike on campus, nobody made sure that he was alright at first. Initially, I was under the assumption that one of the students who was closer to the incident would respond before I arrived, so I did not feel like it was my responsibility to intervene. By the time I reached the student, nobody had checked on him so I asked if he was alright. The other bystanders who walked past before I approached the incident were most likely under the same assumption that somebody else was going to intervene.

This excerpt demonstrates the student's ability to understand upstanding behavior in an isolated incident-a bike accident-that might have injured the student involved. The student was able to apply bystander intervention theory to the actions of other bystanders in the situation. Such understanding demonstrates a traditional understanding of upstanding behavior and the situations in which upstanding may occur. By Week 3, however, after course discussions on theories of justice and bystander theory and use of the heuristic, 
students were able to orient to upstanding using some more sophisticated, structural visions of justice in mind, rather than disconnected situations. For example, Student 2 wrote:

Upstanding in this case would be striving to include all interested people in all groups in order to create feelings of inclusion. An upstander may notice that certain organizations or groups have separated themselves or certain individuals are not represented and then strive to ensure these groups become inclusive or that all individuals are represented.

A way that students experienced broadening in their understandings of justice and upstanding was in the realization that upstanding could be achieved through different kinds of actions. By Week 4 and continuing throughout the course, the historical cases, paired with historical thinking activities and the heuristic (Fig. 1), seemed to have a powerful influence on how students reconstructed upstanding as action that is multidimensional in form. As Student 10 writes:

The historical cases have shown me that upstanding can take many forms. Whether you're leading a strike or simply photographing unjust working conditions, you can make a difference.

This newly constructed understanding seems especially important in helping students realize the tangibility of upstanding for justice. The students' analyses of upstanders from history, whom they had not previously learned about, may have provided the students more realistic avenues to see themselves as "everyday" upstanders for justice. Furthermore, students used the heuristic to "map" these individual actions relative to larger collective action. Student 11 put these new understandings to words in the following way:

Studying the two previous cases caused me to understand how upstanding does not always have to be a significant revolutionary act. Sometimes, upstanding is just calling attention to a problem folks don't know exists. For Lewis Hine this was his go-to strategy. Although his work only captured natural conditions for children laborers, his pictures moved thousands of folks within the child labor movement. It was interesting to see that upstanding is not always immediate. Both of the folks discussed in class started an upstanding movement that was not made mainstream until after a long time.

As captured in this quote, this student recognized that in whatever form upstanding for justice takes, it can be work that goes unrecognized, and the upstander themself may ultimately be unaware of its effects.

The historical cases and heuristic also seemed to complicate students' notions of upstanding by helping them recognize in a new way the power of collective upstanding for justice. About the many ways to upstand, Student 11 writes, "At first, upstanding seemed like it had to be taking action on your own, but I now understand that you can upstand in smaller ways as part of a group." And, Student 1 was able to draw a similar conclusion 
from a different historical case, that of Clara Lemlich an early 20th-century female labor organizer. As she shared in her writing:

I was able to see how a group of people with a common interest are able to come together and stand up. It made me contemplate if beginning upstanding is easy when you have support, when you have similar people with similar interests willing to stand up with you. My conclusion for now is that it definitely is easier and maybe more effective even when a group voices and intervenes to make a difference.

This reflection captures the continuum between individual and collective action represented in the heuristic. Overall, students were able to understand that upstanding for justice may differ from traditional bystander intervention in multiple ways, including the use of both individual and collective action and organizing those actions to upstand in multiple related incidents of injustice rather than a single event.

\section{Grounding upstanding in context and identity}

By far the most frequent and salient theme that emerged from the student data was the recognition of identity and context in the upstanding for justice process. This provided evidence that students gained insight into upstanding as a contested act, one in which an individual may experience competing instincts and conflictual personal investments. By Week 4, after students had experiences with bystander theory, theories of justice, the heuristic and historical cases, student reflections provided ample evidence of how they were able to situate upstanding within the particular context of its manifestation. The following excerpt from a student journal entry demonstrates this awareness:

This week we looked at some background information and events surround Clara Lemlich. These readings looked upon how she fought for Equal Workers rights in 20th Century America by standing up to Factory owners and demanding for better working conditions. There were two things that stood out for me and made me look at Upstanding in a different way: The fact that Clara was a Minority woman, but was still able to cause ripples in the system and how she did it was what interested me. She chose to intervene while evaluating the risks of what it might result in. In our discussions about upstanding, the biggest factor that goes into the decision of intervening is to weigh the risk against the reward. And even though the risk seemed to be high for Clara (the beatings and physical assault) she saw the reward as being worthy of intervening.

Some students even recognized the power of primary historical sources in helping them fully understanding the importance of context in upstanding:

Looking at historical sources from the same time period as the upstanding individual helped us understand how difficult it really was to be an upstander at the time. For instance, it could be really easy for us to oversimplify Ida B. Wells' 
actions. It is clear to us in our present-day context that lynching was immoral and brutal. Thus, we could consider it very easy to take a stand against such a blatantly unjust behavior. However, looking how marginalized African American citizens were 150 years ago and how white supremacists ruled with fear made us realize how truly difficult it was for Ida to take a stand during that time period. Only preserved primary sources could convey such a strong message.

As the student reflections convey, the students' conceptualizations of upstanding for justice grew in complexity throughout the opportunities to learn about bystander theory, read and discuss political philosophy, analyze historical cases of upstanding, and contemplate how the heuristic can illustrate both upstanding actions which support justice and the context of those actions.

\section{Discussion}

While we anticipated and hoped that the instructional practices we developed would cultivate new understandings and beliefs of upstanding for justice, we found some aspects of our original heuristic of upstanding for justice to be more powerfully emerging from the data than other ideas. First, students engaged with new ideas of justice and understood the importance of defining a personal vision of justice that upstanding achieves. While upstanding action may take many different forms, students were very aware of how context and individual identity bounded such action. However, the recognition of this influence very much focused on historical cases. Students largely ignored current context and identity in discussions of contemporary issues of upstanding and justice which may speak to either the selection of issues of injustice which have popular support among college age youth (e.g., marriage equality, DACA immigration) or a lack of students' recognition of their own privilege in addressing injustice. Both of these factors would set students apart from many of the upstanders identified in the historical cases we reviewed. Even by the end of the course, many students continued to focus on individual upstanding actions, with limited identification of collective upstanding especially when considering contemporary issues. In our original heuristic, we tried to balance individual and collective action, in much the same way the Pyramid of Hate differentiated these actions, with the understanding that justice can be achieved only through collective dismantling of systems of oppression (Anti-Defamation League, 2018). To this end, "upstanding for justice" must recognize current power structures and individual/collective agency to change such structures. In the initial heuristic and in our own thinking, we tried to recognize that upstanding actions would need to employ agency to dismantle oppressive structures and systems. However, few students made connections to systems of power and oppression during the course. Overall, the course demonstrated the utility of the heuristic in supporting the thinking of the course participants, especially as a way to "map," or consider, examples of historical and contemporary upstanding.

This research also fills voids in a number of literature fields. For one, it offers new understanding of the power of historical thinking strategies, such as contextualizing and considering perspective, to help students contemplate upstanding behavior. Second, it 
provides empirical evidence of theoretical claims about the how upstanding behavior is about more than interpersonal action. Finally, it expands the ways in which bullying and school climate literature conceptualizes work necessary to combat bullying behavior in schools and offers evidence of undergraduates' engagement with those new conceptualizations. Given the current call in the bullying prevention literature for the use of a socioecological model to explore and address issues of school bullying (Espelage, 2014; Swearer et al., 2010), this work may give consideration to new ways to tie such interpersonal actions as bullying within the school to broader injustice in society and suggests broader acts of upstanding for justice outside of the school may influence conditions within it.

As in any research, there are important limitations to consider with these findings. For one, because of the small sample and contextually laden research design, our findings should not be generalized to other undergraduate students or other instructors. While we did not attempt to prove the effect of these practices, the data from this case do provide some evidence of the promising practice of the curriculum and pedagogies of the course which represent an intersection of bystander intervention and civic development. While not equally, each of the practices within the course were indicated by students as pivotal in their increasingly complex understandings of upstanding for justice.

\section{Conclusion and implications}

This research has important implications for upstanding, historical thinking research and the practitioner fields of bullying prevention and civic education. First, the findings build upon the limited literature which ties school bullying behavior to larger societal patterns of discrimination and bigotry. However, students' thinking in the course suggest that such issues of justice may be addressed with upstanding behavior, much like in incidents of school bullying. Further research is necessary to understand how such upstanding in the community may influence student behaviors within the school. In addition, the use of historical thinking, case studies, and the heuristic suggests that issues of school climate and civic action may be addressed curricularly. These tools proved to be effective in helping students to better understand justice, upstanding, and factors that influence upstanding behavior. Further research should test elements of the course, including the heuristic, with not only additional college students but also students in elementary, middle, and high school. Such actions would further test the curricular approaches of using heuristics, historical case study, and even political philosophy to supporting upstanding and bullying prevention.

Our findings also have implications for institutions of higher education. Given higher education's commitment to supporting students' civic development and identity, this course provides a direct, curricular way for students to address issues of social justice and plan for upstanding behaviors related to injustices which they seek to address.

Finally, our findings have implications related to both upstanding and social justice. Throughout the course, we created and supported students' thinking around a definition of upstanding that was both broad and directional, in that it included behavior beyond individual incidents (e.g., bullying, emergency) which supported social justice. The field of upstanding research, both within schools and beyond, could build upon these findings 
to further define upstanding behavior which supports and ultimately achieves justice. Such research could also further our initial ideas of "upstanding for justice," related to utilization of heuristics which account not only for upstanding behaviors but also contextual factors such as identity, structure, agency, individual, and collective action. Ultimately, this study just begins to explore what it means to stand up for justice and how young people can be assisted in making sense of it.

Declaration of Conflicting Interests - The authors declare no potential conflicts of interest with respect to the research, authorship, and/or publication of this article.

Funding - The preparation of this article was supported by the Institute of Education Sciences (IES), U.S. Department of Education, through Grant \#R324B160033 to the University of Nebraska-Lincoln. The opinions expressed are those of the authors and do not necessarily represent views of the Institute or the U.S. Department of Education.

\section{References}

Anti-Defamation League (2018) Pyramid of Hate. Available at: https:/www.adl.org/sites/default/files/ documents/pyramid-of-hate.pdf

Banyard V, Plante E and Moynihan M (2004) Bystander education: bringing a broader community perspective to sexual violence prevention. Journal of Community Psychology 32: 61-79.

Baston C (1995) Prosocial motivation: why do we help others? In: Tesser A (ed.) Advanced Social Psychology. New York: McGraw-Hill, 333-374.

Beaumont E, Colby A, Ehrlich T et al. (2006) Promoting political competence and engagement in college students: An empirical study. Journal of Political Science Education 2(3): 249-270.

Biddex JP (2014) Development through dissent: campus activism as civic learning. New Directions for Higher Education 167: 73-85.

Bohm A (2004) 5.13 Theoretical Coding: Text Analysis in Grounded Theory. A Companion to Qualitative Research. Thousand Oaks, CA: SAGE, 270.

Bryant AN, Gayles JG and Davis HA (2011) The relationship between civic behavior and civic values: a conceptual model. Research in Higher Education 53(1): 76-93.

Butin DW (2012) Rethinking the "apprenticeship of liberty": the case for academic programs in community engagement in higher education. Journal of College \& Character 13(1): 1-8.

Chabot H, Tracy T, Manning C et al. (2009) Sex, attribution and severity influence intervention decisions of informal helpers in domestic violence. Journal of Interpersonal Violence 24: 1696-1713.

Chatters SJ and Zalaquett CP (2018) Bullying prevention and prejudice reduction: assessing the outcome of an integrative training program. The Journal of Individual Psychology 74(1): 20-37.

Dahl HM, Stoltz P and Willig R (2004) Recognition, redistribution and representation in capitalist global society: an interview with Nancy Fraser. Acta Sociologica 47(4): 374-382.

den Heyer K (2003) Between every "now" and "then": a role for the study of historical agency in history and citizenship education. Theory and Research in Social Education 31(4): 411-434.

Engestrom Y (2000) Activity theory as a framework for analyzing and redesigning work. Ergonomics 43(7): 960-974.

Espelage DL (2014) Ecological theory: prevention youth bullying, aggression, and victimization. Theory into Practice 53: 257-264. 
Facing History and Ourselves (2018). Available at: https://www.facinghistory.org/

Farley J (2018) Teachers as obligated bystanders: grading and relating administrator support and peer response to teacher direct intervention in school bullying. Psychology in the Schools 55: 10561070.

Finley A (2011) Civic learning and democratic engagements: a review of the literature on civic engagement in post-secondary education. Available at: https://www.uwec.edu/Usenate/SenateCommittees/ APC/121 030LiteratureReviewCivicEngagement.pdf

Fischer P, Greitemeyer T, Pollozek F et al. (2006) The unresponsive bystander: are bystanders more responsive in dangerous emergencies? European Journal of Social Psychology 36: 267-278.

Garcia S, Weaver K, Darley J et al. (2009) Dual effects of implicit bystanders: inhibiting vs. facilitating helping behavior. Journal of Consumer Psychology 19: 215-224.

Latane B and Darley J (1970) The Unresponsive Bystander: Why Doesn't He Help? Englewood Cliffs: Prentice-Hall, Inc.

Lave J and Wenger E (1991) Situated Learning: Legitimate Peripheral Participation. Cambridge: Cambridge University Press.

Lopez MH, Levine P, Both D et al. (2006) The 2006 civic and political health of the nation: a detailed look at how youth participate in politics and communities. Available at: http://www.civicyouth .org/ PopUps/2006_CPHS_Report_update.pdf

McIntyre A (1994) Guilty bystanders? On the legitimacy of duty to rescue statutes. Philosophy \& Public Affairs 23(2): 157-191.

Merriam SB (1998) Qualitative Research and Case Study Applications in Education. Revised and Expanded from "Case Study Research in Education." San Francisco, CA: Jossey-Bass Publishers.

Merriam SB (ed.) (2002) Qualitative Research in Practice: Examples for Discussion and Analysis. San Francisco, CA: Jossey-Bass.

Narismulu P (2013) A heuristic for analysing and teaching literature dealing with the challenges of social justice. Teaching in Higher Education 18(7): 784-796.

National Center for Education Statistics (NCES) (2014) Table 322.10 Bachelor's Degrees Conferred by Postsecondary Institutions, by Field of Study: Selected Years, 1970-71 through 2012-13. Available at: https://nces.ed.gov/programs/digest/d14/tables/dt14_322.10.asp

Olweus D (2003) A profile of bullying at school. Educational Leadership 60: 12-17.

Olweus D, Limber S, Crocker Flerx V et al. (2007) Olweus Bullying Prevention Program: Schoolwide Guide. Center City: Hazelden.

Pozzoli T and Gini G (2013) Why do bystanders of bullying help or not? A multidimensional model. The Journal of Early Adolescence 33(3): 315-340.

Prentice D and Miller D (1996) Pluralistic ignorance and the perpetuation of social norms by unwitting actors. Advances in Experimental Social Psychology 28: 161-209.

Rossman GB and Rallis SF (2012) Learning in the Field: An Introduction to Qualitative Research. Thousand Oaks, CA: SAGE.

Rüsen J (1987) Historical narration: foundation, types, reason. History and Theory 26(4): 87-97.

Salmivalli C (2014) Participant roles in bullying: how can peer bystanders be utilized in interventions? Theory into Practice 53(4): 286-292.

Salmivalli C, Lagerspetz K, Bjorkqvist K et al. (1996) Bullying as a group process: participant roles and their relations to social status within the group. Aggressive Behavior 22: 1-15.

Schwartz S and Gottlieb A (1980) Bystander anonymity and reactions to emergencies. Journal of Personality and Social Psychology 39(3): 418-430. 
Shibata A, Mori T, Okamura M et al. (2008) An economic analysis of apathetic behavior: Theory and experiment. The Journal of Socio-Economics 37: 90-107.

Stake RE (1995) The Art of Case Study Research. Thousand Oaks, CA: SAGE.

Sutton J and Smith PK (1999) Bullying as a group process: an adaptation of the participant role approach. Aggressive Behavior 25: 97-111.

Swearer S and Hymel S (2015) Bullying and discrimination in schools: exploring variations across student subgroups. School Psychology Review 44(4): 504-509.

Swearer SM, Espelage DL, Vaillancourt T et al. (2010) What can be done about school bullying? Research to educational practice. Educational Researcher 39: 38-47.

The National Task Force (2012) The National Task Force on Civic Learning and Democratic Engagement: a Crucible Moment: College Learning and Democracy's Future. Washington, DC: Association of American Colleges and Universities. Available at: https://www.aacu.org/sites/default/files/files/ crucible/Crucible_508F.pdf

Time V, Payne B and Gainey R (2010) Don't help victims of crime if you don't have the time: assessing support for good Samaritan laws. Journal of Criminal Justice 38: 790-795.

Upstander (n.d.) In the English Oxford living dictionary online. Available at: https://en.oxford dictionaries.com/definition/upstander

van den Bos K, Muller P and van Bussel A (2009) Helping to overcome intervention inertia in bystander's dilemmas: behavioral disinhibition can improve the greater good. Journal of Experimental Social Psychology 45: 873-878.

VanSledright B (2004) What does it mean to think historically ... and how do you teach it. Social Education 68(3): 230-233.

Villegas AM and Lucas T (2002) Preparing culturally responsive teachers: rethinking the curriculum. Journal of Teacher Education 53(1): 20-32.

Vygotsky LS (1980) Mind in Society: The Development of Higher Psychological Processes. Cambridge, MA: Harvard University Press.

Welsh K (2014) Using nonfiction texts to teach resistance in a democratic society. The English Journal 103(5): 42-46.

Wenik J (1985) Forcing the Bystander to get involved: a case for a statute requiring witnesses to report crime. The Yale Law Journal 94: 1787-1806.

Westheimer J (2015) What Kind of Citizen? Educating Our Children for the Common Good. New York: Teachers College Press.

Westheimer J and Kahne J (2004) What kind of citizen? The politics of educating for democracy. American Educational Research Journal 41(2): 237-269.

Who Is an Upstander? (n.d.) Available at: https://www.facinghistory.org/resource-library/video/ who-upstander (accessed 4 April 2018).

Wineburg SS, Martin D and Monte-Sano C (2012) Reading Like a Historian: Teaching Literacy in Middle and High School History Classrooms. New York: Teachers College Press.

Yanikoski R (2004) Leadership perspectives on the role of character development in higher education. New Directions for Institutional Research 122: 7-23.

You're an Upstander! (n.d.) Available at: http://www.thebullyproject.com/be_an_upstander (accessed 4 April 2018).

Zimmer B (2016) How high school girls won a campaign for "Upstander." The Wall Street Journal, 9 September. Available at: https://www.wsj.com/articles/how-high-school-girls-won-a-campaignfor-upstander-1473436114 